\title{
ESTIMATING THE STOCK OF GLASS EELS IN AN ESTUARY BY MARK-RECAPTURE EXPERIMENTS USING VITAL DYES
}

\author{
C. BRIAND (1), D. FATIN (1), E. FEUNTEUN (2), G. FONTENELLE (3)
}

(1) Institution d'Aménagement de la Vilaine, 56130 La Roche Bernard, France, tél.: 33299908844 .

E-mail : cedric.briand@lavilaine.com

(2) Laboratoire de biologie et d'environnement marin, Université de La Rochelle, 17042 La Rochelle cedex, France, tél.: 33-5 46458338.

E-mail : eric.feunteun@univ-Ir.fr

(3) Département halieutique, École Nationale Supérieure Agronomique, 35042 Rennes, Cedex, France, tél.: 33-2 23485533.

E-mail : fontenel@roazhon.inra.fr

Reçu le 10 septembre 2004

Accepté le 20 juin 2005

Received September 10, 2004

Accepted June 20, 2005

\begin{abstract}
Glass eels (Anguilla anguilla) arriving after the fishing season in the Vilaine estuary (France) were caught by boat and at a trapping ladder located at a blocking dam upstream in the estuary. They were marked with Bismarck brown, rhodamine B or neutral red, and released into the estuary. The effect of marking on behaviour, mortality and recapture differed according to the dye and concentration used. The glass eels also differed in response to marking according to their origin. Estuarine glass eels were clearly desynchronized in their selective tidal stream transport and left the release area after a few tidal cycles. Trapped glass eels were less sensitive to marking. They remained in the release area and were recaptured in larger number both in the trapping ladder and in the estuary. These results supported a model of two behavioral fractions in the estuary: flow-carried migrants and active glass eels with stronger rheotactic behaviour. The proportion of active glass eels in the estuary shifted from none for the two weeks after the fishery closure, to $10 \%$ value of the total stock. At the trapping ladder, the migration ended in June each year, while a large stock was still present in the estuary. These observations favour the interpretation of a short duration of the active phase at this site followed by the transition towards a more benthic behavior. The daily efficiency of the trapping ladder was calculated as $4 \%$ of the active stock from both stock estimations and average recapture rate. This value was consistent with the low annual efficiency of the trapping ladder, calculated as $30 \%$ of the estuarine stock of glass eels that arrived after the fishing season.
\end{abstract}

Key-words: Anguilla anguilla, vital dye, glass eel, marking recapture. 


\section{ESTIMATION DE STOCK DE CIVELLES EN ESTUAIRE PAR MARQUAGE-RECAPTURES À L'AIDE DE COLORANTS VITAUX}

\section{RÉSUMÉ}

Les civelles (Anguilla anguilla) arrivant après la fin de la saison de pêche dans l'estuaire de la Vilaine (France) ont été capturées à l'aide d'un bateau de pêche et sur une passe piège située à l'amont de l'estuaire sur le barrage qui limite la progression du stock migrant. Elles ont ensuite été marquées à l'aide de Brun-Bismarck, rhodamine $B$ et rouge neutre et relâchées en estuaire. L'effet du marquage sur le comportement, la mortalité et les recaptures, a différé en fonction du colorant et de la concentration utilisés. Les civelles ont également montré une réponse différente au marquage en fonction de leur origine. Celles qui étaient prélevées en estuaire étaient clairement désynchronisées dans leur transport tidal sélectif et ont quitté la zone de lâché après quelques cycles de marées. Celles qui provenaient de la passe ont été moins sensibles au marquage. Elles sont restées dans la zone de lâché, et ont été recapturées en plus grand nombre à la fois dans la passe et dans l'estuaire. Ces résultats permettent de proposer un modèle ou deux fractions comportementales sont distinguées dans l'estuaire, des civelles en phase de migration portée et des civelles en migration active avec un comportement rhéotactique plus marqué. La proportion de civelles actives en estuaire est passée de zéro, dans les deux semaines qui suivent la fermeture de la pêcherie à une valeur limitée à $10 \%$ du stock total. La migration a stoppé en juin chaque année alors qu'un stock important restait en estuaire. Ces observations sont favorables à l'hypothèse d'une durée courte de la migration active suivie par la transition vers un comportement benthique. L'efficacité journalière de la passe à civelles a été calculée à $4 \%$ du stock actif, à la fois à partir des estimations de stock et des taux moyens de recapture. Ces valeurs sont cohérentes avec une efficacité annuelle faible de la passe, calculée à $30 \%$ du stock estuarien de civelles arrivé après la saison de pêche.

Mots-clés : Anguilla anguilla, colorant vital, civelle, marquage-recapture.

\section{INTRODUCTION}

Glass eels migrate from the sea into freshwater using two different behavioral patterns: selective tidal stream transport (STST) and active migration. Selective tidal stream transport is a common trait in the genus Anguilla observed in most temperate and tropical species (DEELDER, 1958; JELLYMAN, 1979; SHELDON and McCLEAVE, 1985; SUGEHA et al., 2001; DOU and TSUKAMOTO, 2003, TESCH, 2003).

STST consists of a semidiurnal vertical migration (CREUTZBERG, 1958; CREUTZBERG, 1961). Glass eels use tidal currents for shoreward migration and progression in the estuaries. At flood tide, they move up below the halocline when the estuary is stratified, otherwise they swim through the entire water column. During ebb tide then remain buried in the substratum (McCLEAVE and KLECKNER, 1982). The timing of their ascent into the water column is probably influenced by an endogenous biological clock (TESCH, 1965; McCLEAVE and WIPPELHAUSER, 1987), which may be set by differences in water odor between ebb and flood tide currents (CREUTZBERG, 1959) or tide reversal (WIPPELHAUSER and McCLEAVE, 1988). From downstream to upstream sectors of the estuary, the time spent in the water column is rather constant while the duration of tide gets shorter. This difference leads to the accumulation of glass eels at a point, located downstream from the tidal limit, where STST is no longer resulting in a net-up estuary transport (McCLEAVE and WIPPELHAUSER, 1987). The location of this accumulation area depends on the strength of tide and the freshwater discharge (GASCUEL, 1986). Therefore, the density of glass eels increases from the mouth of the estuary towards freshwater and then decreases sharply from the accumulation point 
(TESCH, 2003; SHELDON and McCLEAVE, 1985; SORENSEN and BIANCHINI, 1986; DE CASAMAJOR, 1998). The spatial variation can be matched with a temporal evolution, with an increasing abundance from December to March-April, although the observation of such trends would depend on the balance between recruitment and exploitation by the glass eel fisheries (GASCUEL et al., 1995).

Active migration was first described by DEELDER (1958) as a progressive trend to migrate counter current towards freshwater. At the freshwater interface (TESCH, 2003), or more certainly from the point where they accumulate (McCLEAVE and WIPPELHAUSER, 1987), glass eels change their behavioral pattern (CREUTZBERG, 1961), and migrate counter current. Such an active migration is involved in the crawling behavior that glass eels display on glass eel trapping ladders (TESCH, 2003; LEGAULT, 1988; McGOVERN and McCARTHY, 1992) and in their tendency to school and to swim along the banks described for Anguilla anguilla (VILTER, 1944; TESCH, 2003) and A. australis and dieffenbachi (JELLYMAN, 1979).

The behaviour shift from STST to active migration corresponds to a shift in the influence of environmental conditions. Active migrants swim more rapidly and orientate counter current from water turbulence when they cross an area of freshwater discharge (DEELDER, 1958). Such a shift could explain the inversion of the effect of river flow passing from strongly negative to strongly positive from March to June near Rhode Island (USA) (MARTIN, 1995), although this result might also be the consequence of collinearity between flow and temperatures (JESSOP, 2003).

The time lag before active migration is influenced by water temperature. Probably no active migration occurs below a $6-8^{\circ} \mathrm{C}$ threshold for Anguilla anguilla (CREUTZBERG, 1961; TESCH, 2003).

When glass eels turn into yellow eels, the massive run exhibited by active glass eels is gradually replaced by a more diffuse colonization of the watershed. This process consists of low migration rates (MORIARTY, 1986; LOBÓN-CERVIÁ et al., 1995; WHITE and KNIGHTS, 1997; IBBOTSON et al., 2002). The active phase probably has a short duration, illustrated by very few glass eels encountered in inland waters. Indeed, glass eels are observed on dams at the tidal head of estuaries (GASCUEL, 1986; McGOVERN and McCARTHY, 1992) but are rarely seen far upstream from the tidal limit in freshwater streams (MORIARTY, 1986; NAISMITH and KNIGHTS, 1988; DUTIL et al., 1989; LOBÓNCERVIÁ et al., 1995; JESSOP, 2000).

These findings support the idea of a transition from STST to an active migration and then to the benthic behaviour of yellow eels. However, timing and duration of each phase are still unknown.

We investigated the stock of glass eels arriving at the Vilaine estuarine dam after the end of the commercial fishing season using dye mark-recapture, glass eel traps and experimental fishing. The overall objectives of this study were to: (1) present a markrecapture method based on vital dye marking, (2) describe and discuss the presence of two behavioural sub-units in the stock, (3) calculate and discuss stock numbers and ladder efficiency.

\section{MATERIAL AND METHOD}

\section{Site description}

The study was conducted in the estuary of Vilaine watershed (N. W. France $\left.10400 \mathrm{~km}^{2}-\mathrm{N} 2^{\circ} 30^{\prime} \mathrm{E} 47^{\circ} 30^{\prime}\right)$. The Arzal estuarine dam blocks the tide $12 \mathrm{~km}$ from the river mouth. Close to the dam, the tidal range is 7 meters, and water velocity at the gates prevents glass eels from swimming further upstream. A professional fishery of 150 boats 
is located a short distance downstream from the dam (Figure 1). Fishing is authorised between November and April. During our study, commercial fishing stopped on April 6 in 1998, April 2 in 1999 and April 15 in 2000. Maximum catches of the fishery are made in January and February, and few glass eels are likely to escape during the fishing season (BRIAND et al., 2003a). Since 1996, an eel-trapping ladder made of two crawling gutters and a resting pool, has been located on the dam (LEGAULT, 1992; BRIAND et al., 2002). The estuarine temperatures and freshwater flow are recorded at the dam.
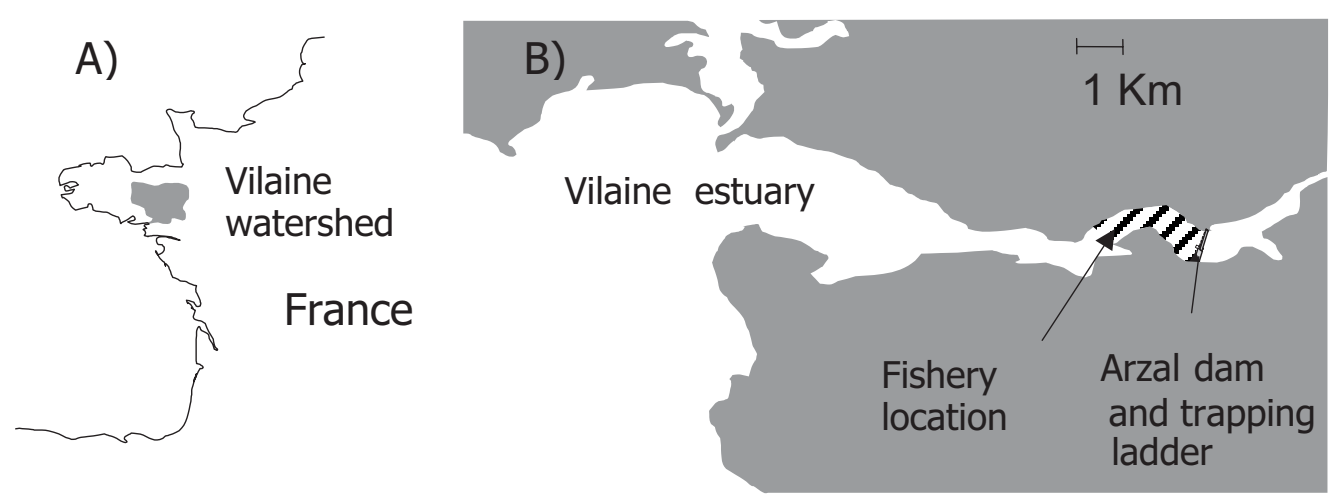

\section{Figure 1}

A) Location of the Vilaine watershed; B) Map of the Vilaine estuary.

Figure 1

A) Localisation du bassin versant de la Vilaine ; B) Carte de l'estuaire de Vilaine.

\section{Trapping ladder monitoring and experimental fishing}

The trapping ladder (trap) was monitored daily from 1998 to 2000 . Estuarine sampling trips were conducted in 1999 and 2000, with a boat at high tide three nights per week from April 7 to May 19 in 1999 and April 17 to May 19 in 2000. The boat towed two circular $1.20 \mathrm{~m}$ diameter nets of $2 \mathrm{~mm}$ mesh size at the water surface.

Estuarine and trap catches were handled in the same way. The glass eel counts were estimated from wet weight of glass eels measured after a short draining in the net. The wet weights were calibrated on samples weighting from 10 to $100 \mathrm{~g}$, at each estuarine sampling trip and at least once a week at the trapping ladder. The mean wet weight decreased from $0.32-0.34 \mathrm{~g}$ in mid-April to $0.20-0.25 \mathrm{~g}$ in early June.

This measure of wet weight resulted in an overestimate of the number of glass eels of $5 \%$ because less draining was applied during current handling, when aliquots (200$500 \mathrm{~g})$ were used.

Pigment developmental stages were analysed three times a week on samples of 100 glass eels, after anaesthetised with phenoxy-ethanol. The classification scheme of ELIE et al. (1982) was used.

\section{Mark-recaptures}

Mark-recaptures operations were started after the end of the fishing season, as soon as enough glass eels were caught. Three different dyes were used for marking: neutral red (NR), Bismarck brown (BB) and rhodamine $B(R B)$ in order to limit the overlap between mark-recapture experiments. Glass eels were bathed for three to five hours in 
an aerated tank of water. The dye concentrations were those suggested by CANTRELLE (1981) and GASCUEL $(1987 a, b)$. However, the concentration of NR was increased to

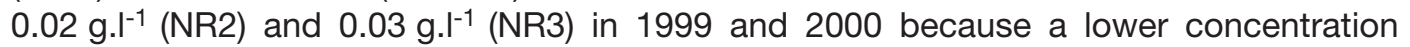
$\left(0.01{\left.\mathrm{~g} . \mathrm{I}^{-1}\right)}\right.$ remained visible for a shorter period. A concentration of $0.05 \mathrm{~g}^{-\mathrm{l}^{-1}}$ for four hours was chosen for RB after preliminary tests. Such a concentration allowed us to discriminate marked individuals for one week (Table 1). All samples of marked glass eels were rested for several hours before being released into the estuary near the dam. All releases occurred at flood tide except one marking in 1998 that was released at ebb tide. After release, the glass eels were recaptured on the ladder and during estuarine sampling trips and the stained glass eels were counted. Stock size was estimated for each daily recapture, and the number of marked glass eels in the population was calculated as the number released in the estuary minus the number of marked glass collected on the previous recaptures. For each marking, a reference sample of 100 individuals was kept in estuarine water to estimate the mortality and the colour fading. The water was aerated and renewed daily. Colour fading was measured daily as the percentage of glass eels marked in the reference sample, measured in conditions similar to the nightly counting of glass eels. The number of stained glass eel recaptured was divided by this percentage to account for unchecked marked glass eels. Stock estimates stopped when less than $50 \%$ of the batch was scored as coloured.

\section{Table 1}

Experimental conditions applied during marking; density = number of glass eels per liter.

Tableau 1

Conditions expérimentales appliquées durant les marquages, densité = nombre de civelles par litre.

\begin{tabular}{lccl}
\hline \multicolumn{1}{c}{ Dye } & Concentration & Duration & Density \\
\hline Neutral red (NR1) 1998 and 1999 & $0.01 \mathrm{~g} / \mathrm{L}$ & $5 \mathrm{~h}$ & $200 \mathrm{n} / \mathrm{L}$ \\
Neutral red (NR2) 1999 and 2000 & $0.02 \mathrm{~g} / \mathrm{L}$ & $5 \mathrm{~h}$ & $200 \mathrm{n} / \mathrm{L}$ \\
Neutral red (NR3) 1999 (1 trial) & $0.03 \mathrm{~g} / \mathrm{L}$ & $5 \mathrm{~h}$ & $200 \mathrm{n} / \mathrm{L}$ \\
Bismarck Brown (BB) 1998-2000 & $0.05 \mathrm{~g} / \mathrm{L}$ & $3 \mathrm{~h}$ & $200 \mathrm{n} / \mathrm{L}$ \\
Rhodamine B (RB) 2000 & $0.05 \mathrm{~g} / \mathrm{L}$ & $4 \mathrm{~h}$ & $200 \mathrm{n} / \mathrm{L}$ \\
\hline
\end{tabular}

In a first trial (1998), the collection of glass eels for marking and subsequent recapture was limited to the trapping ladder. In 1999 and 2000, the collection, marking and recapture of samples was performed both on the trapping ladder and in the estuary during experimental trips.

\section{Stock assessment}

The active stock $(A)$ is defined to be the stock of glass eels that try to migrate upstream the dam. The STST stock (S) corresponds to glass eels using selective tidal stream transport (McCLEAVE and WIPPELHAUSER, 1987). We used the basic equation of the "Petersen estimate" $N=n_{1} n_{2} / m_{2}$ where $N=$ stock, $n_{1}=$ number of marked glass eels released, $n_{2}=$ total number in daily recapture, $m_{2}=$ number of marked glass eels in daily recapture. This equation assumes that the following assumptions are true: (a) the population is closed, (b) marked and unmarked glass eels have an equal probability of being caught (SEBER, 1982). We ignored the two other assumptions i.e., loss of marking and errors linked to the report of marked individuals. The Petersen estimate was refined by 
dividing both the marked population and the whole stock into STST and active behaviours. Hence: $a_{1}=$ active part of the marked population and $s_{1}=$ STST part of the marked population. Depending on the origin and the place of recapture, mark recaptures fall into four sections and provided either an estimate of the active stock (A) or of the total stock $\mathrm{N}=\mathrm{A}+\mathrm{S}$ :

(1) Trap-trap: when both marked and recaptured glass eels came from the trapping ladder, all marked glass eels were active $\left(n_{1}=a_{1}\right)$ and the active stock was estimated as $A=a_{1} n_{2} / m_{2}$.

(2) Estuary-estuary: Similarly, mark-recaptures in the estuary gave an estimate of the whole stock $\mathrm{N}=\mathrm{n}_{1} \mathrm{n}_{2} / \mathrm{m}_{2}$.

(3) Trap-estuary: When samples were marked on the trapping ladder, and recaptured in the estuary, we assumed that active marked eels $\left(a_{1}\right)$ had the same probability of being caught as estuarine eels. Then $\mathrm{N}=\mathrm{n}_{1} \mathrm{n}_{2} / \mathrm{m}_{2}=\mathrm{a}_{1} \mathrm{n}_{2} / \mathrm{m}_{2}$.

(4) Estuary-trap: This last case was the less obvious. When we marked glass eels in the estuary, the marked sample was made of active and STST glass eels $\left(n_{1}=a_{1}+s_{1}\right)$. Only the active fraction $\left(a_{1}\right)$ could be recaptured on the ladder and we estimated $A=a_{1} n_{2} /$ $m_{2}$. To calculate the stock from the known $n_{1}$ value, we had to assume that there was a constant proportion of active glass eels in the estuary. This proportion must have been the same for marked glass eels $\left(n_{1}\right) a_{1}=\delta n_{1}$ as for the whole stock $A=\delta N$, so $A=a_{1} n_{2} /$ $\mathrm{m}_{2}=\delta \mathrm{n}_{1} \mathrm{n}_{2} / \mathrm{m}_{2}$, thus $\mathrm{N}=\mathrm{n}_{1} \mathrm{n}_{2} / \mathrm{m}_{2}$.

We estimated the stock for each recapture and used successive daily estimates to monitor the effect of marking on glass eel behaviour. We based the trend analysis on the following considerations: if marked and unmarked glass eels have the same behaviour, and the population is closed, then we expect to have steady estimates for successive recaptures. An increasing trend may be the consequence of immigration, but emigration will not be detected if it affects equally marked and unmarked glass eels.

For each recapture, we calculated the confidence intervals (0.95) using a normal approximation of the binomial law (SEBER, 1982).

\section{RESULTS}

\section{Trap monitoring and experimental fishing}

During estuarine trips, mean daily catches were $9.9 \mathrm{~kg}$ in 1999, $3.6 \mathrm{~kg}$ in 2000 and total catches amounted to $198 \mathrm{~kg}$ (18 trips) in 1999 and $54 \mathrm{~kg}$ (15 trips) in 2000. On the trapping ladder, experiments started later as glass eels only started climbing 9 to 15 days after the end of the fishing season. Mean daily catches were $6.5 \mathrm{~kg}$ in 1998, $3.4 \mathrm{~kg}$ in 1999 and $1.5 \mathrm{~kg}$ in 2000 . The total weights of glass eels trapped during the season were 696, 249 , and $73 \mathrm{~kg}$ respectively (Figure 2).

Pigment stages changed from a majority of young stages VB and VIAO just after the end of commercial fishery to a majority of VIA2 to VIA3 stages one month later. In 1999, "rejuvenation" was observed on the ladder from May 12 to 18. It followed the second migration peak observed on the ladder from May 7 to 17 (Figure 2), which indicated the arrival of two successive glass eel waves in 1999 (Figure 4). No similar trend occurred in 1998 and 2000. In these years, the regular trend in pigment stages indicated a continuous ageing of the glass eel population (Figures 3, 5).

In addition, pigment stages were more advanced on the ladder than in the estuary (Figures 3, 4). For 1999, the difference was highly significant (Chi square test, $\mathrm{P}<0.001$ ) on each of the seven sampling dates. For 2000, the difference was highly significant (Chi square test, $P<0.001)$ on 8 occasions, and significant $(P<0.05)$ for May 3,5 and 13. 
Bull. Fr. Pêche Piscic. (2005) 378-379 : 23-46 - $29-$

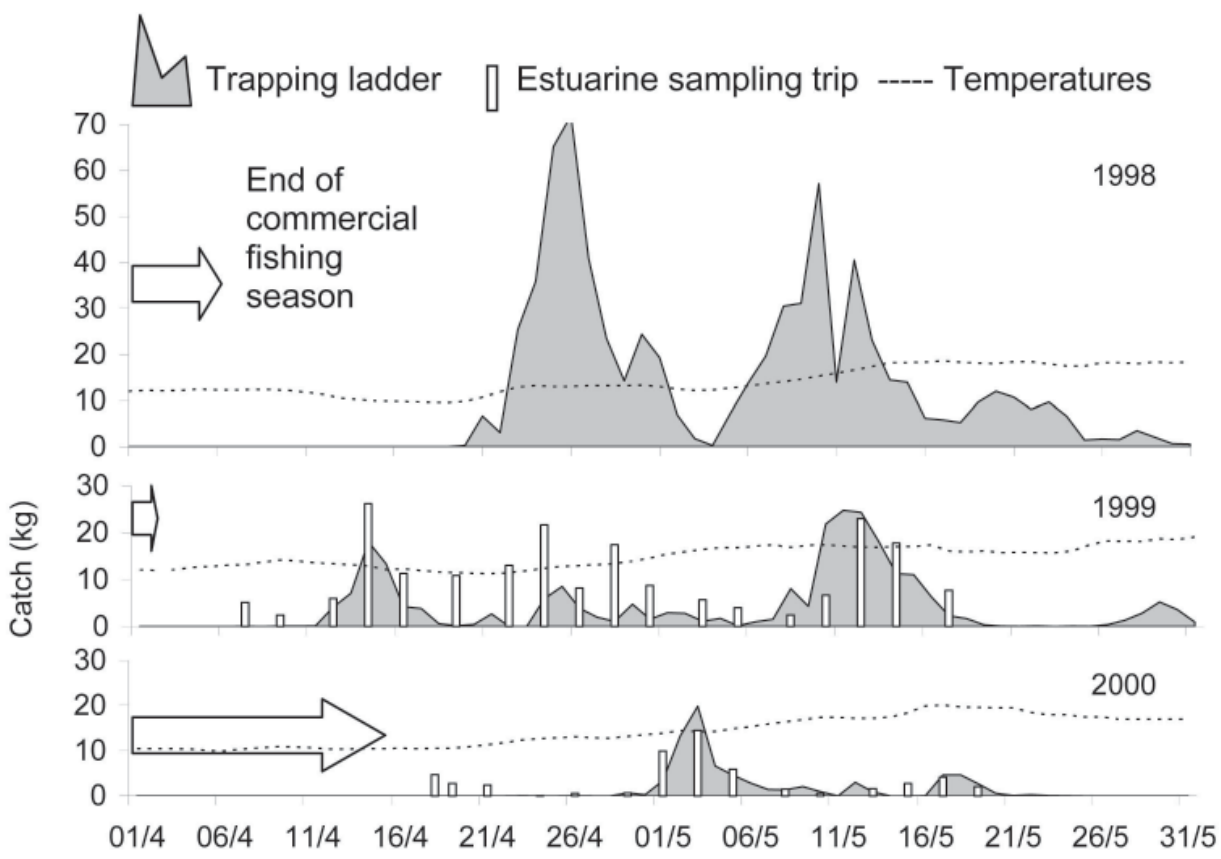

\section{Figure 2}

April range of the commercial fishing season (arrows), daily catches for estuarine sampling trips and the trapping ladder, estuarine water temperatures in 1998, 1999 and 2000.

\section{Figure 2}

Extension de la saison de pêche en avril (flèches), captures journalières pour les pêches expérimentales en estuaire et pour la passe, et températures en estuaire en 1998, 1999 et 2000.

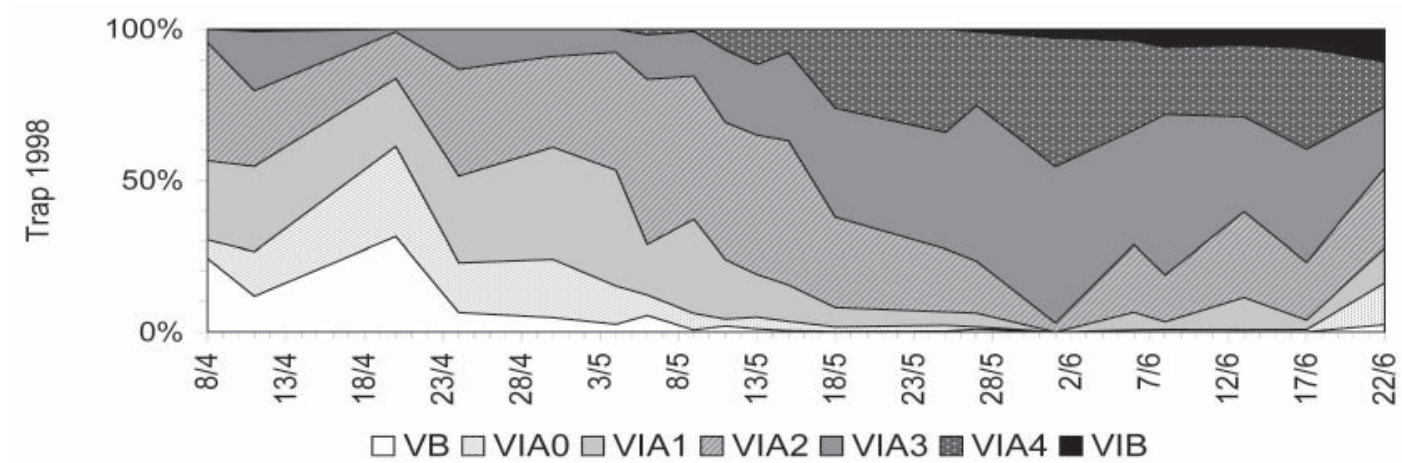

Figure 3

Seasonal changes in pigment stages for samples collected on the trapping ladder in 1998.

Figure 3

Évolution des stades pigmentaires pour les échantillons collectés sur la passe en 1998. 


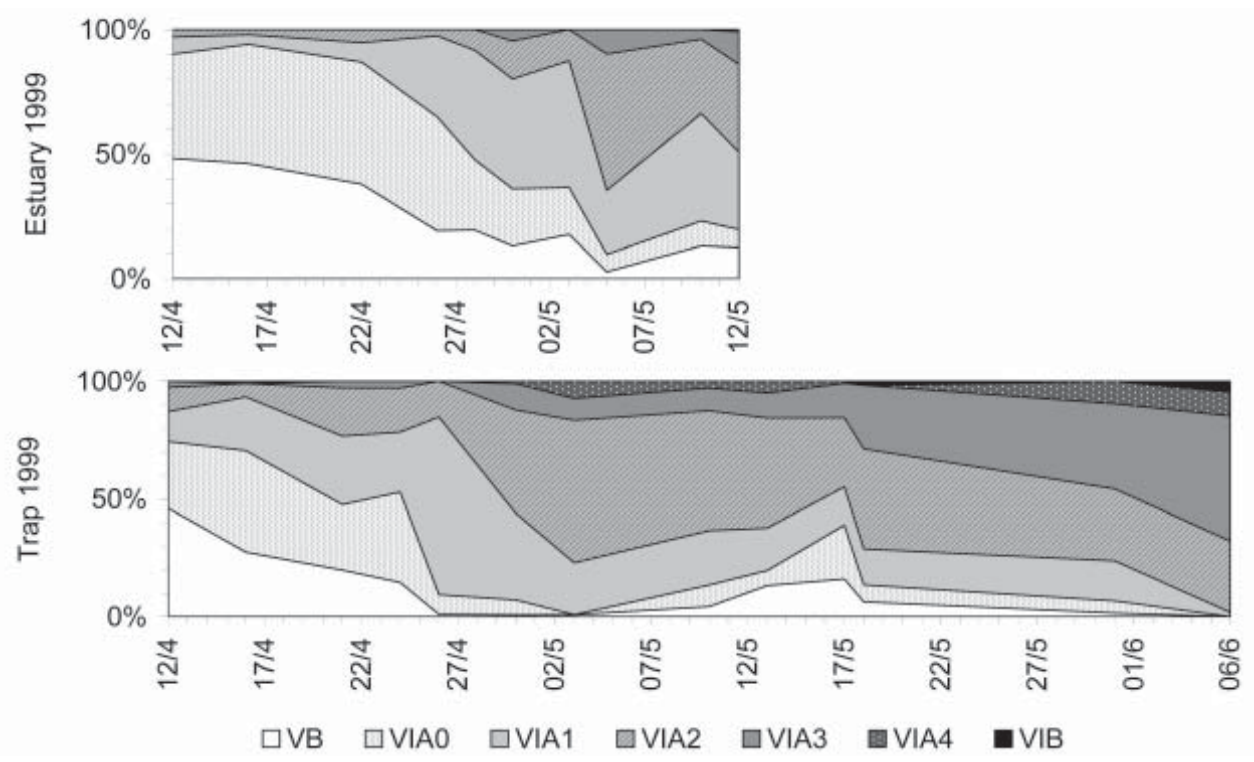

\section{Figure 4}

Seasonal changes in pigment stages for samples collected on the trapping ladder and in the estuary in 1999.

\section{Figure 4}

Évolution des stades pigmentaires pour des échantillons collectés sur la passe et en estuaire en 1999.

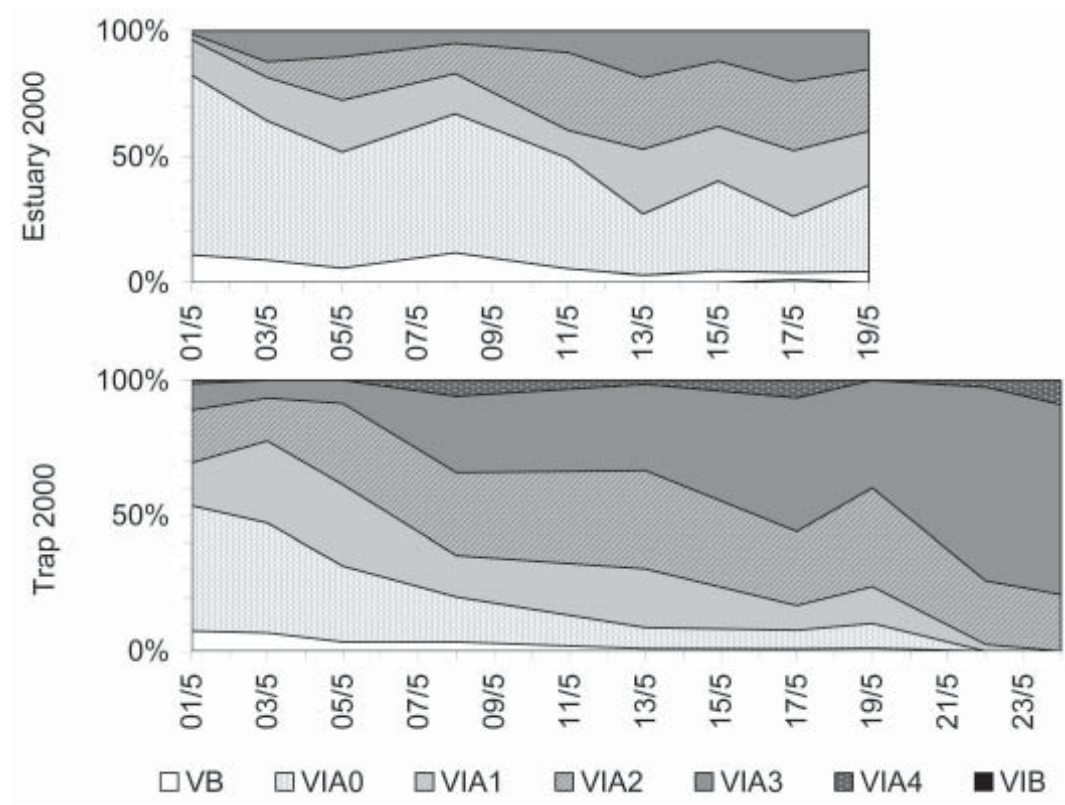

\section{Figure 5}

Seasonal changes in pigment stages for samples collected on the trapping ladder and in the estuary in 2000.

\section{Figure 5}

Évolution des stades pigmentaires pour des échantillons collectés sur la passe et en estuaire en 2000. 


\section{The dye marking effect}

NR1 had little effect on behaviour. Marking and post marking mortalities were low (Table 2). All trap-trap mark-recaptures showed an increase in the marked fraction between the first and second day after release, which points to a post-release handling effect, or trap avoidance, but only on the first day. Increasing the concentrations of neutral red to NR2 did not increase the mortality on the reference samples. At $0.03 \mathrm{~g} . \mathrm{I}^{-1}$, mortality reached $41 \%$ after five days for the reference sample, compared with mean values of $6 \%$

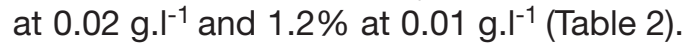

\section{Table 2}

Mean value and range of mortality rate for trap and estuarine samples; $\mathbf{N}=$ number of experiments; handling and fishing = cumulative mortality after trapping or fishing and handling process; marking = mortality at release, one day after marking; post marking = cumulative mortality of reference sample after 5 days.

\section{Tableau 2}

Moyenne et valeurs extrêmes des taux de mortalité pour les civelles collectées en estuaire et dans la passe; $\mathbf{N}=$ nombre d'expérimentations ; handling and fishing $=$ mortalité cumulée après capture ou piégeage et manipulation ; marking = mortalité au moment du lâché, une journée après le marquage ; post marking = mortalité cumulée de l'échantillon témoin après cinq jours.

\begin{tabular}{lcccc}
\hline \multicolumn{1}{c}{ Dye used } & $\mathbf{N}$ & $\begin{array}{c}\text { Handling } \\
\text { \& fishing }\end{array}$ & Marking & Post marking \\
\cline { 2 - 5 } & \multicolumn{4}{c}{ Trap samples } \\
\hline Bismarck brown 0.05 g/L & 4 & 0 & $0.5(0.1-1)$ & $0.9(0-2.8)$ \\
Rhodamine B 0.05 g/L & 1 & 0 & 0.2 & 0 \\
Neutral red 0.01 g/L & 4 & 0 & $0.1(0.1-0.2)$ & $1.2(0-2.7)$ \\
Neutral red 0.02 g/L & 3 & 0 & $0.0(0-0.1)$ & $7.3(1.1-17.8)$ \\
\hline & & Estuarine samples & & $2.9(0-6)$ \\
Bismarck brown 0.05 g/L & 5 & $4.1(1.3-9.2)$ & $2.3(0.7-7.6)$ & $8.3(6.8-9.8)$ \\
Rhodamine B 0.05 g/L & 2 & $2.6(2.6-2.7)$ & $0.3(0.1-0.4)$ & $6.0(1-15)$ \\
Neutral red 0.02 g/L & 3 & $0.9(0.2-2.3)$ & $1.0(0.2-2.7)$ & 41 \\
Neutral red 0.03 g/L & 1 & 0.8 & 1.3 & \\
\hline
\end{tabular}

Bismarck brown's reference sample mortalities were low: (almost zero) for trap marking, but higher (2.9\% after 5 days) for estuarine marking. A synchronous marking with NR2 and BB was conducted on an estuarine sample in May 2000. NR2 stock estimates were $23 \%$ higher for trap-estuary and 25\% higher for trap-trap, indicating that NR2 recaptures were fewer than BB (May 20, 2000, Figures 6, 7).

The only trap marking with RB was stopped after a trap failure. Synchronous marking of an estuarine sample with BB and RB gave 34\% higher estuary-trap estimates for BB than for RB (May 3, 2000, Figure 7). The immediate mortality after marking with RB was low and post-marking mortality was zero for trap marking (Table 2). In contrast, the mean post marking mortality (8.3\% after 5 days) was high for estuarine marking, in line with the large overall mortality of estuarine samples. 


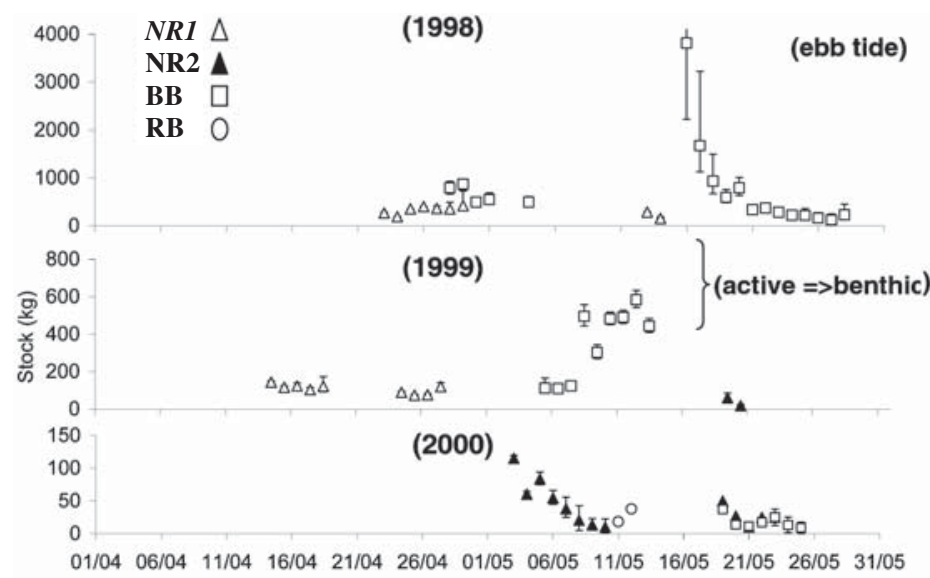

Figure 6

Trap-trap mark-recapture results for 1998, 1999 and 2000; successive estimates and $95 \%$ C.I. for marking performed with neutral red $0.01 \mathrm{~g} / \mathrm{L}$ (NR1), neutral red $0.02 \mathrm{~g} / \mathrm{L}$ (NR2), Bismarck brown (BB) $0.05 \mathrm{~g} / \mathrm{L}$ and rhodamine B (RB) $0.05 \mathrm{~g} / \mathrm{L}$.

Figure 6

Résultats des marquage-recaptures passe-passe pour 1998, 1999 et 2000, estimations successives et intervalles de confiance à $95 \%$ pour des marquages réalisés avec du rouge neutre $0,01 \mathrm{~g} / \mathrm{L}$ (NR1), du rouge neutre à $0,02 \mathrm{~g} / \mathrm{L}$ (NR2), du brun Bismarck (BB) à $0,05 \mathrm{~g} / \mathrm{L}$ et de la rhodamine $\mathrm{B}(\mathrm{RB})$ à $0,05 \mathrm{~g} / \mathrm{L}$.

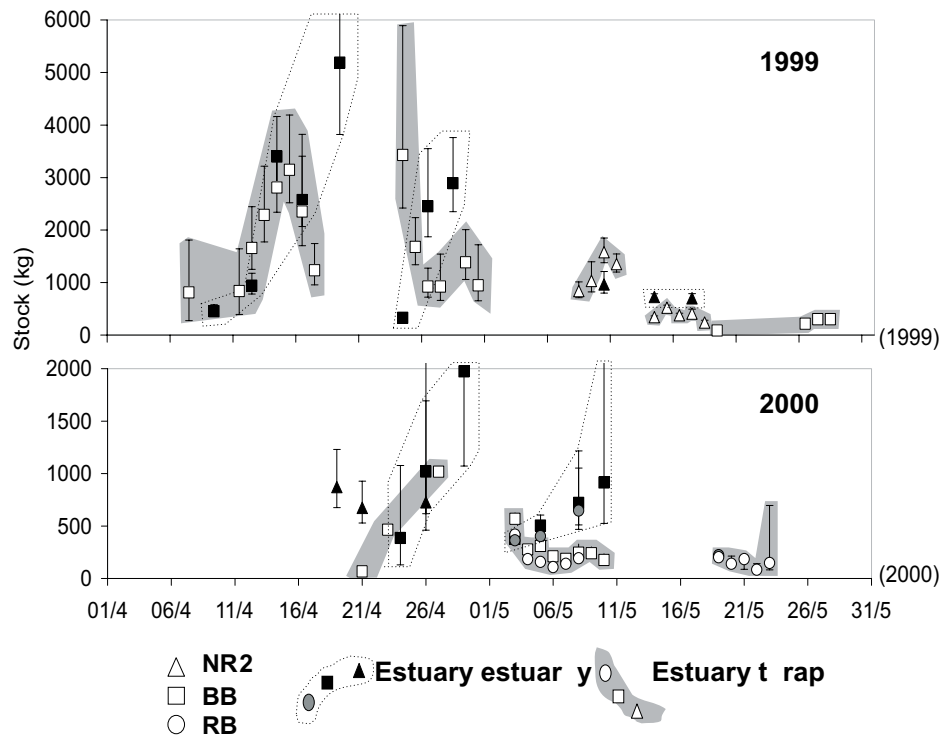

Figure 7

Estuary-estuary and estuary-trap mark-recapture results for 1999 and 2000, successive estimates and $95 \%$ C.I. for marking performed with neutral red $0.02 \mathrm{~g} /$ L (NR2), Bismarck brown (BB) $0.05 \mathrm{~g} / \mathrm{L}$ and rhodamine B (RB) $0.05 \mathrm{~g} / \mathrm{L}$.

Figure 7

Résultats des marquage-recaptures estuaire-estuaire et estuaire-passe pour 1999 et 2000, estimations successives et intervalles de confiance à $95 \%$ pour des marquages réalisés avec du rouge neutre à $0,02 \mathrm{~g} / \mathrm{L}$ (NR2), du brun Bismarck (BB) à $0,05 \mathrm{~g} / \mathrm{L}$ et de la rhodamine $\mathrm{B}(\mathrm{RB})$ à $0,05 \mathrm{~g} / \mathrm{L}$. 


\section{Mark-recaptures}

Twelve mark-recapture operations were conducted from trap samples from 1998 to 2000 , eleven in the estuary in 1999 and 2000. The marked sample size ranged from 6000 to 21000 glass eels. The main outcome from these experiments is that marked glass eels coming from the trapping ladder were easier to recapture than those from the estuary. Indeed, recapture rates on the trapping ladder were higher for glass eels marked in samples collected on the ladder (trap-trap 3.7\% and 3.3\% in 1999 and 2000) than in those collected in the estuary (estuary-trap $0.4 \%$ and $1.4 \%$ ). Similarly, recapture rates in the estuary were higher for trap-estuary (1.2 and 2.5\%) than for estuary-estuary (1 and

\section{Table III}

Daily recapture rate and marking duration for the marking of samples collected on the trapping ladder and in the estuary from 1998 to 2000; in bold = marking during a migration peak; NR1 = neutral red $0.01 \mathrm{~g} / \mathrm{l} ; \mathrm{NR2}=$ neutral red $0.02 \mathrm{~g} / \mathrm{l}$; NR3 = neutral red $0.03 \mathrm{~g} / \mathrm{l} ; \mathrm{BB}=$ Bismarck brown $0.05 \mathrm{~g} / \mathrm{L} ; \mathrm{RB}=$ Rhodamine $\mathrm{B}$ $0.05 \mathrm{~g} / \mathrm{l}$. a The first fishing that occurred three hours after marking provided $6 \%$ recapture rate, the more representative means for the two last recapture days were $0.4 \%$. b There were very small catches (some glass eels) on the ladder for this period; ${ }^{c}$ The overall percentage does not take into account the first operations having very low recaptures.

Tableau III

Taux de recapture journalier et durée des marquages des échantillons de civelles collectés en estuaire et dans la passe de 1998 à 2000 ; en gras = marquage durant un pic de migration. ${ }^{a}$ La première pêche réalisée trois heures après le marquage a conduit à un taux de recapture de $6 \%$, les deux jours suivants donnent un taux de recapture plus représentatif de $0.4 \%$. ${ }^{b}$ Très peu de captures (quelques civelles) sur la passe à cette période ${ }^{c}$ La moyenne ne prend pas en compte les deux premières opérations qui ont conduit à de très faibles recaptures.

\begin{tabular}{|c|c|c|c|c|}
\hline \multirow[b]{2}{*}{ Operation } & \multicolumn{2}{|c|}{ Trap-trap } & \multicolumn{2}{|c|}{ Trap-estuary } \\
\hline & $\begin{array}{c}\text { Recapture } \\
(\%)\end{array}$ & $\begin{array}{c}\text { Duration } \\
\text { (day) }\end{array}$ & $\begin{array}{c}\text { Recapture } \\
(\%)\end{array}$ & $\begin{array}{c}\text { Duration } \\
\text { (day) }\end{array}$ \\
\hline \multicolumn{5}{|c|}{1998} \\
\hline NR1 21 April & 8.6 & 7 & - & - \\
\hline BB 28 April & 5.3 & 13 & - & - \\
\hline NR1 11 May & 8.6 & 2 & - & - \\
\hline BB 14 May & 1.2 & 15 & - & - \\
\hline Mean & 4.4 & & & \\
\hline \multicolumn{5}{|c|}{1999} \\
\hline NR1 12 April & 5.5 & 5 & 1.2 & 2 \\
\hline NR1 23 April & 4.1 & 3 & 2.3 & 2 \\
\hline BB 03 May & 4.0 & 9 & 0.7 & 4 \\
\hline NR2 18 May & 0.4 & 4 & - & - \\
\hline Mean & 3.7 & & 1.2 & \\
\hline \multicolumn{5}{|c|}{2000} \\
\hline NR2 01 May & 4.3 & 8 & 2.6 & 3 \\
\hline RB 10 May & 6.3 & 3 & 0.8 & 2 \\
\hline NR2 17 May & 1.6 & 6 & 3.5 & 1 \\
\hline BB 17 May & 2.2 & 6 & 4.5 & 1 \\
\hline Mean & 3.3 & & 2.5 & \\
\hline
\end{tabular}


Table III (continued)

Tableau III (suite)

\begin{tabular}{lcccc}
\hline \multirow{2}{*}{ Operation } & \multicolumn{2}{c}{ Estuary-trap } & \multicolumn{2}{c}{ Estuary-estuary } \\
\cline { 2 - 5 } & $\begin{array}{c}\text { Recapture } \\
\text { (\%) }\end{array}$ & $\begin{array}{c}\text { Duration } \\
\text { (day) }\end{array}$ & $\begin{array}{c}\text { Recapture } \\
(\%)\end{array}$ & $\begin{array}{c}\text { Duration } \\
\text { (day) }\end{array}$ \\
\hline & & 1999 & & \\
BB 07 April & 0.2 & 14 & 0.5 & 5 \\
BB 22 April & 0.3 & 6 & $2.5\left(0.4^{\mathrm{a})}\right.$ & $3\left(2^{\mathrm{a}}\right)$ \\
NR3 28 April & 0.1 & 6 & 0.4 & 2 \\
NR2 05 May & 1.0 & 5 & 0.3 & 2 \\
NR2 12 May & $\mathbf{1 . 8}$ & $\mathbf{4}$ & $\mathbf{1 . 5}$ & $\mathbf{2}$ \\
BB 17 May & 0.1 & 7 & - & - \\
Mean & 0.4 & & 1.0 & \\
\hline & & 2000 & & 4 \\
NR2 17 Aprilb & 0.002 & 12 & 0.2 & 3 \\
BB 21 Aprilb & 0.007 & 8 & 0.03 & $\mathbf{4}$ \\
BB 01 May & $\mathbf{1 . 3}$ & $\mathbf{8}$ & $\mathbf{1 . 3}$ & $\mathbf{3}$ \\
RB 01 May & $\mathbf{2 . 4}$ & $\mathbf{6}$ & $\mathbf{1 . 8}$ & \\
RB 17 May & 0.4 & 5 & 0.9 & \\
Mean & $1.4^{\mathrm{c}}$ & & 0.8 & \\
\hline
\end{tabular}

$0.8 \%)$. This difference in mean recapture rates also applied when we compared trap and estuarine markings conducted at the same time (Table 3).

Stock estimates differed between active $(A)$ and total stock $(N)$.

Trap-trap mark-recaptures gave the lowest stock values (Figure 6). For a given marking, successive daily stock estimates were stable or diminished for 9 out of 12 operations (Table 3 ), due to increasing recapture rates of marked glass eels. The very large downward trend in 1998 is related to a release at ebb tide. Two marking operations, April 211998 and May 3 1999, resulted in increasing stock estimates. These experiments matched with the arrival of a new wave of glass eels, illustrated by the first migration peak on the trapping ladder in 1998, and by both a migration peak and a rejuvenation of ladder pigment stages in 1999 (Figure 4).

Estuary-estuary recaptures gave the largest stock estimates. The trends obtained with successive recaptures changed from the beginning to the end of every annual experiment. Shortly after the start of mark-recaptures, in April 1999 and 2000, a quick decrease in recapture rates was reflected in a large increase in the estimated stock size: in 5 days from $100-400$ to $2000-3000 \mathrm{~kg}$. One month later, the trend was less sharp but we could still observe a regular increase in estimates given by estuarine recaptures. For the last operations in mid-May, marking of estuarine samples gave steady stock estimates (Figure 7).

Trap-estuary stock estimates ranged from 260 to $1100 \mathrm{~kg}$ in 1999 and 187 to $263 \mathrm{~kg}$ in 2000. For each marking, estimates showed little variation (20-32\%, Figure 8). For simultaneous releases of marked glass eels, estuary-estuary and trap-estuary estimates were similar a few hours after release, 372 and $328 \mathrm{~kg}$ respectively, but the difference increased from 40 to $73 \%$ after 2 or 3 ebb tides.

Estuary-trap estimates were similar to estuary-estuary ones for the first experiment: very large overestimates were obtained in April 1999 and 2000. Later in May, estuaryestuary estimates still increased while estuary-trap estimates decreased (Figure 7). 


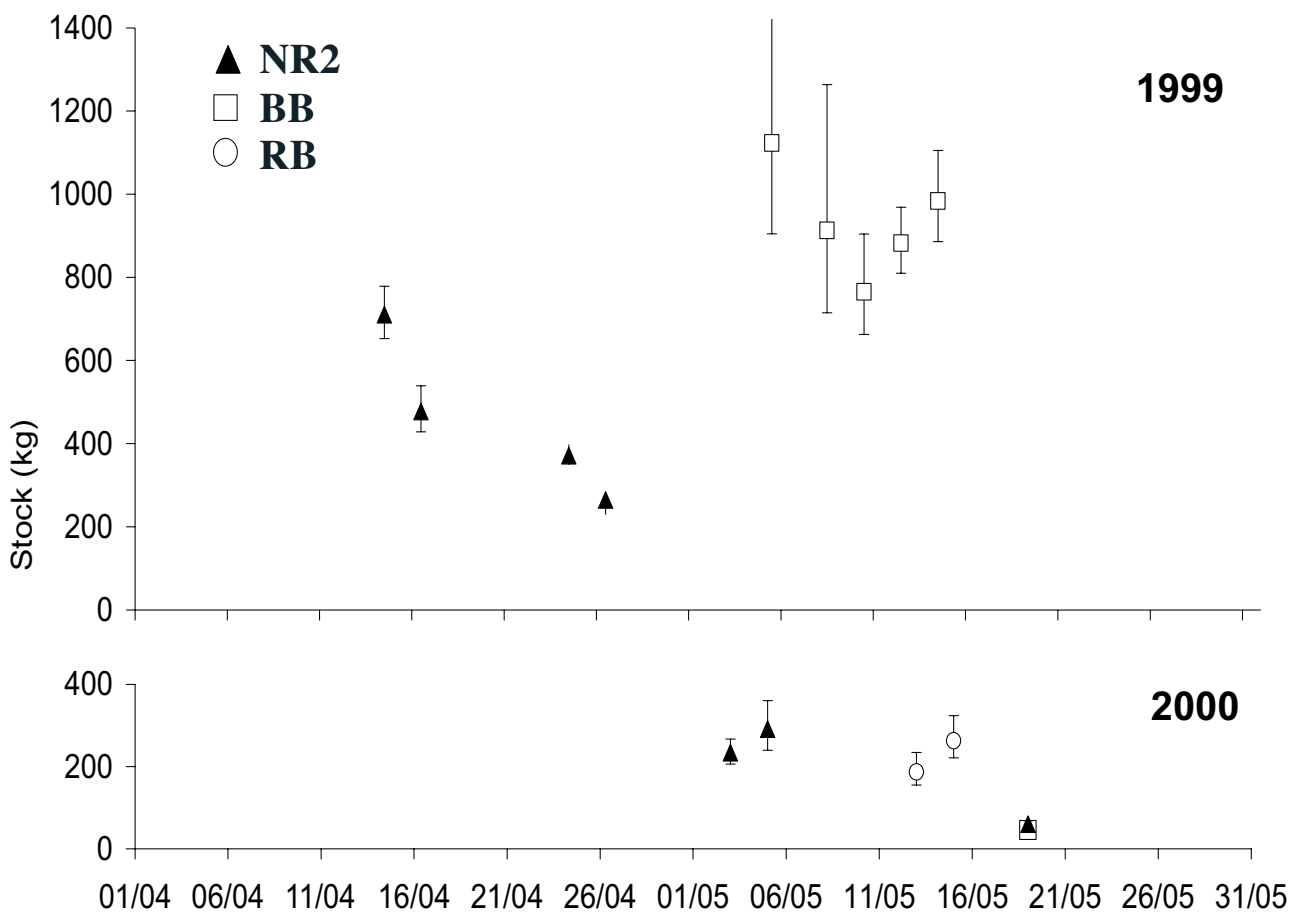

Figure 8

Trap-estuary mark-recapture results, successive estimates and $95 \%$ C.I. for marking performed with neutral red $0.02 \mathrm{~g} / \mathrm{L}$ (NR2), Bismarck brown (BB) $0.05 \mathrm{~g} / \mathrm{L}$ and rhodamine $B$ (RB) $0.05 \mathrm{~g} / \mathrm{L}$.

\section{Figure 8}

Résultats des marquage-recaptures passe-estuaire pour 1999 et 2000, estimations successives et intervalles de confiance à $95 \%$ pour des marquages réalisés avec du rouge neutre à $0,02 \mathrm{~g} / \mathrm{L}$ (NR2) du brun Bismarck (BB) à $0,05 \mathrm{~g} / \mathrm{L}$ et de la rhodamine $B(R B)$ à $0,05 \mathrm{~g} / \mathrm{L}$.

\section{Stock estimation}

According to the analysis of biases linked with dye effect and behaviour (see discussion), it was possible to select some least biased values, and provide some rough estimates of stock abundance (Figures 9 and 10).

The three total stock estimates $(\mathrm{N})$-estuary-estuary, estuary-trap and trap-estuarywere of the same order of magnitude and ranged from 100 to $1100 \mathrm{~kg}$ in 1999 and from 50 to $360 \mathrm{~kg}$ in 2000 (Figures 9A, 10A). These results were larger than the active stock estimates (A), which ranged from 180 to $400 \mathrm{~kg}$ in 1998, 40 to $120 \mathrm{~kg}$ in 1999 and 10 to $30 \mathrm{~kg}$ in 2000 (Figures 6, 9A, 10A).

The active faction of stock represented a small fraction of the estuarine population (10\%). This fraction was quite stable, and there was a year-to-year similarity in relative magnitude found for total stock, active stock, trapping and experimental catches (Figure 11).

Fishing 3 nights per week, for a quarter of the legal duration of the commercial fishery, resulted in a catch of $23 \%$ of the stock estimated during the mark-recapture period in 1999 (6 weeks) and 15\% in 2000 (5 weeks). The trapping ladder efficiency, with reference to the active stock, was $20 \%$ in favourable periods (increasing tide range) but fell to zero in bad conditions (low tide range, large flow). On the basis of mean trapping 


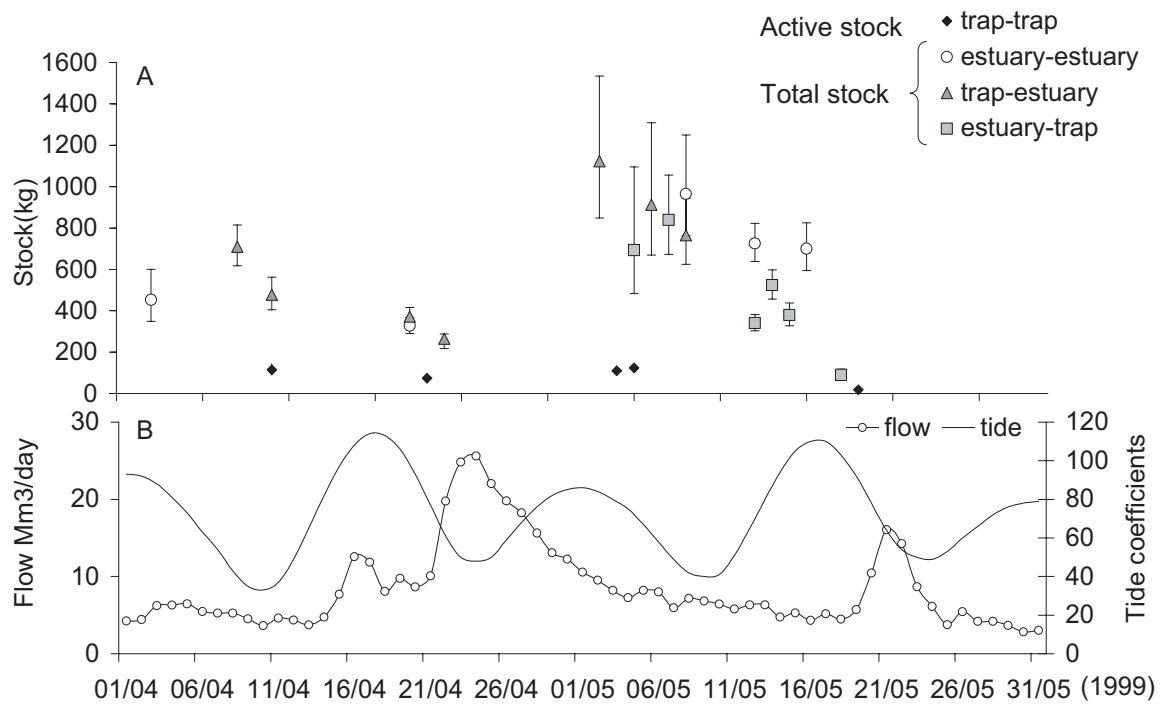

Figure 9

Mark-recapture results for 1999; A) Least biased values for active and total stock estimate with $95 \%$ C.I.; B) Flow and tide coefficients.

Figure 9

Résultats des marquage-recaptures en 1999 ; A) Estimations correspondant aux valeurs les moins biaisées pour le stock actif et le stock total, intervalles de confiance à $95 \%$; B) débit fluvial et coefficients de marée.

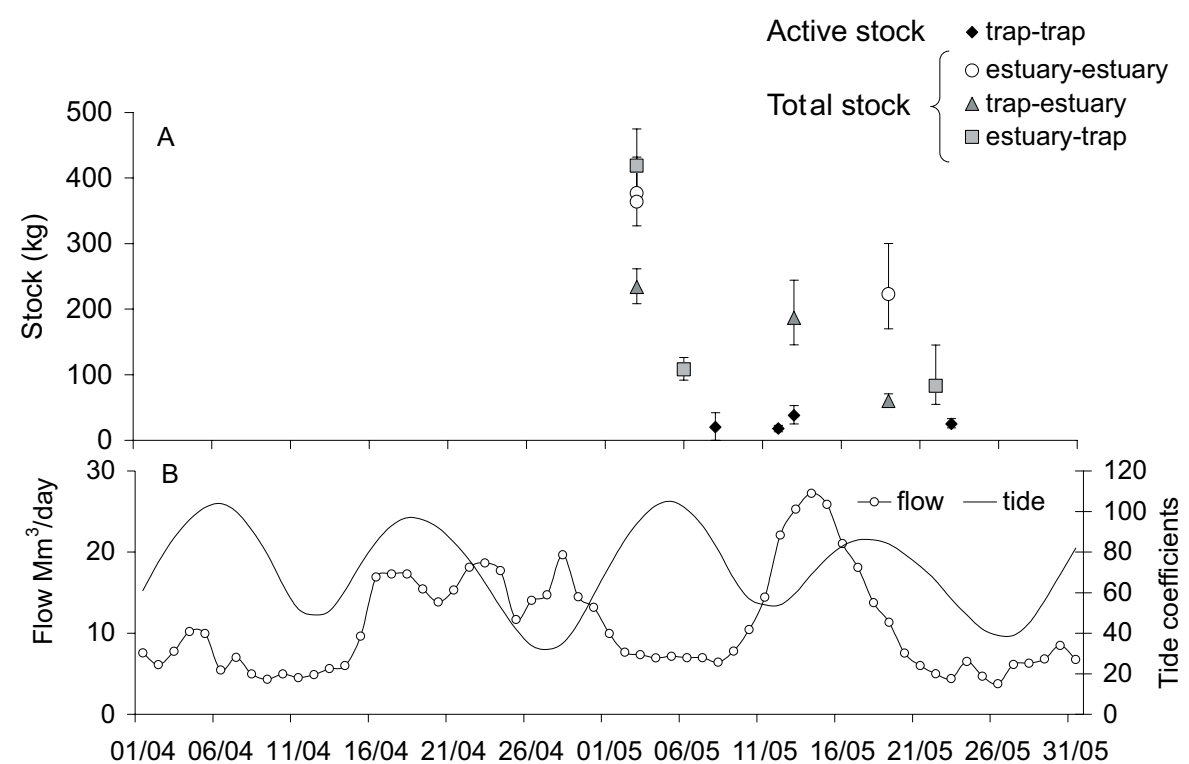

\section{Figure 10}

Mark-recapture results for 2000; A) Least biased values for active and total stock estimate with $95 \%$ C.I.; B) Flow and tide coefficients.

\section{Figure 10}

Résultats des marquage-recaptures en 2000 ; A) Estimations correspondant aux valeurs les moins biaisées pour le stock actif et le stock total, intervalles de confiance à $95 \%$; B) débit fluvial et coefficients de marée. 


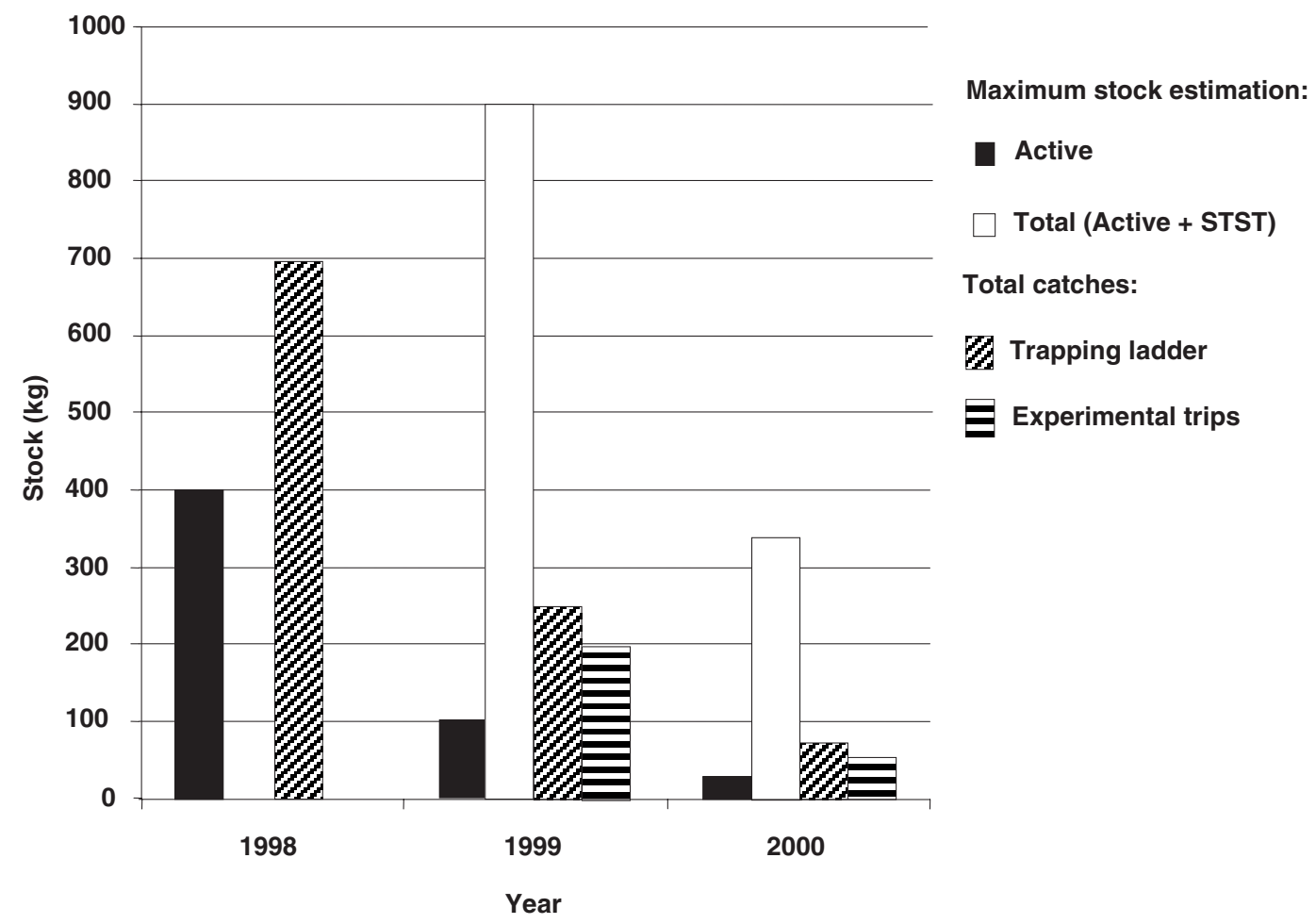

Figure 11

Maximum stock estimates of glass eels obtained with vital dye mark-recapture for active and total stocks and total catches for the trapping ladder and estuarine fishing trips; three year study 1998-2000 in the Vilaine estuary.

\section{Figure 11}

Estimations de stock maximales obtenues à l'aide de marquage-recaptures par des colorants vitaux pour le stock actif et le stock total, captures totales pour la passe et les campagnes expérimentales de pêche, étude sur trois années 19982000 en estuaire de Vilaine.

and previous stock calculations, the average daily efficiency of the ladder, with reference to the active stock, was $3 \%, 3 \%$, and $6 \%$ for the three consecutive years, $4 \%$ on average. The same percentage could have been obtained by averaging the daily recapture rates for trap-trap operations (Table 3).

\section{DISCUSSION}

The initial experimental plan was aiming at reducing the bias linked with open populations in mass mark-recapture experiments by analysing the trend for several days of recaptures. An increasing trend in the same marking recapture would indicate recruitment to the sampling area, while successive marking recaptures with decreasing stock estimates between two operations would suggest emigration. This consideration, together with the necessity to have a clear mark also for night-time use, led to an increase in the dye concentrations.

After three years of experiments, it appears clearly that the initial objective was beyond reach, that increasing the dye concentration was an error and that the marked and unmarked glass eels did not have equal probabilities of being caught. Marking has 
an effect on behaviour and probably on longer-term mortality, and at first look estimates were extremely variable and doubtful. However, a closer examination revealed meaningful patterns in the results.

\section{Dye marking}

Except very early in the season and for some dyes where a clearly noxious effect might have increased the mortality, the common trend for recaptures on the trapping ladder was an increase in marked fraction between first and $2^{\text {nd }}$ day of release attributed to trap avoidance or more likely post-release handling effect. The analysis of this trap avoidance behaviour, combined with post-marking mortalities in the control sample and the recapture rate from synchronous BB/NR2 and BB/RB experiments, allows us to classify the effect of dyes and concentrations on behaviour. NR1 and RB provided relatively unbiased stock values. Marking with BB did not affect short-term survival but probably affected behaviour. Higher concentrations of NR affected both behaviour and mortality rates.

This analysis was later confirmed by tests on climbing behaviour of glass eels performed on an experimental ramp. Climbing did not seem to be affected by either NR1 or RB (with results from fewer experiments). But higher dye concentrations NR2 and NR3 modified both climbing ability and survival of glass eels. It is worth noticing that, although $\mathrm{NR} 2$ did not increase the mortality in the control sample, it induced an increase in mortality to $80-90 \%$ on the samples tested on the ramp. This larger mortality was probably the consequence of increased handling (unpublished results).

CANTRELLE (1981) has reported these effects and set the NR threshold concentration at $0.01 \mathrm{~g}^{-\mathrm{I}^{-1}}$ for reasons of toxicity. For $\mathrm{BB}$, the results were less clear as there was no mortality in the control samples. However, the decreasing trend in trap-trap experiments showed a probable effect on behaviour, migration rate (JESSOP, 2000) and swimming ability (CANTRELLE, 1984). Interestingly, there was little behavioural effect noted with the use of a FX fluorescent dye on Anguilla japonica glass eels (TZENG, 1984).

\section{Behaviour of trap vs. estuarine samples}

The behaviour was different for a marking applied to samples coming from the trapping ladder or from the estuary. Indeed, the recapture rate was higher, both for trap and estuarine recaptures, when samples were collected in the trap (Table 3). Subsequent recaptures of trap samples also provided stable daily stock estimates with reduced confidence intervals, indicating a large daily recapture rate (Figure 6, 8). In contrast, when the marked sample was collected in the estuary, subsequent recaptures led to increasing daily stock estimates corresponding to a decrease in recaptures of marked glass eels (Figure 7). These results were observed in all experiments, except where the noxious effect of dye was clearly apparent.

The increase in estuarine stock estimates, too large to reflect any possible stock trend, is explained by an exit from the "catchable stock" of marked glass eels following STST, for the few days following their release. The vertical migration of glass eels in the water column is timed by an endogenous clock whose rhythm is set by external factors. The timing of the response to tidal currents (CREUTZBERG, 1959; McCLEAVE and WIPPELHAUSER, 1987; WIPPELHAUSER and McCLEAVE, 1988) appears to drop after three days without an efficient synchronizing signal (BARDONNET et al., 2003). When kept in the laboratory with only a light-dark cycle, glass eels lose their tide-driven behaviour (DOU and TSUKAMOTO, 2003).

Fishing, handling and marking apparently disturbed the glass eels vertical migration rhythm and they were possibly flushed out of the estuary during the ebb tide, although settlement in the estuary and mortality (dye-induced direct or indirect due to predation following a dye-effect) are also possible. Similar results were obtained on marked glass 
eels identified as STST migrants because they were collected in winter. CANTRELLE (1981) indicated that marked glass eels released $40 \mathrm{~km}$ upstream in the estuary of the Gironde (France) were recaptured in the neighbouring estuaries of the Seudre and the Charente. Mark-recaptures in the Sèvre Niortaise (France) induced 95\% downriver departure and very low recapture rates for both NR1 and BB (GASCUEL, 1987a). Recaptures in neighbouring estuaries were also observed.

In contrast, active migrants remained within the sampling area close to the dam and this behaviour explains the larger recapture rates and the temporal stability of trap-estuary and trap-trap estimates during successive recaptures. Similarly, JESSOP (2000) using BB $0.01 \mathrm{~g}^{-1} \mathrm{l}^{-1}$ on active Anguilla rostrata glass eels that had previously ascended a trapping ladder didn't recapture any glass eels $1.3 \mathrm{~km}$ downstream from the release site.

The response of estuarine glass eels to marking changed during the season, and the same change was observed in 1999 and 2000. For the first mark-recaptures both estuary-estuary and estuary-trap daily stock estimates increased sharply indicating diminishing recaptures. For the second mark-recapture operations, estuary-estuary daily stock estimates increased while estuary-trap estimates decreased. This trend can be explained by the ongoing transition from STST to active behaviour. For early recaptures, after the end of the commercial fishing period, the estuarine glass eel population was mainly composed of new recruits. Indeed, the highly efficient fishery in the Vilaine leads to a very low escapement (BRIAND et al., 2003a), which is illustrated by the large proportion of young stages VB and VIAO in the estuary (>80\%) at the beginning of the experimental trips (Figures 4,5). Therefore, the first estimates using estuary-trap and estuary-estuary were probably mainly based on STST migrants. This explains why they show an inconsistent increase in daily estimated stock values. It also explains why, while sampling trips attested the presence of glass eels in the estuary, they did not climb the ladder (Figure 2). Later in the season, a larger part of active migrants in the estuary accounts for lower departure rates from the estuary (Figure 7 ).

The pattern of ascent of active glass eels on the trapping ladder was still clearly based on tide: no glass eel climbed the ladder at low tide while the maximum of ascent was reached one hour before high tide. Since those glass eels also depended on tide, their rhythm should have been perturbed. Trap glass eels were gently caught with hand nets while estuarine glass eels were fished. Was as the difference between trap and estuarine samples the consequence of a more rheotactic behaviour or the consequence of a harsher treatment of estuarine glass eels? The seasonal shift in behaviour of estuarine glass eels, all caught with a fishing boat, is an argument favouring a larger rheotactism.

\section{Transition to the benthic behaviour}

The migration stops in June each year when most glass eels have evolved to the VIA2 stage in the trap. The exit from both STST and the active sub-unit of the stock is reflected by the rejuvenation of pigment stages in July (Figure 3). It also matches with the lowest weight and condition factor recorded for glass eels ascending the trap. Such a description is consistent with the assumption that recruitment has ceased and that glass eels switch to benthic behaviour. After having changed their behaviour, they would be caught neither in surface experimental fishing nor in the trapping ladder. The stoppage in migration could also be explained by higher mortality. But it is not possible to determine the respective role of settlement and mortality rate from mark-recapture studies. As this last sub-unit of stock was not sampled, the transition to benthic behaviour was difficult to demonstrate directly from trends in mark-recapture experiments. However, it is a possible source of bias for stock estimates. Shifting from active to benthic behaviour may explain the increasing trap-trap stock estimates observed for BB marking in May 1999. Indeed the trap sample was made of $70 \%$ of stages $\geq$ VIA2. Two weeks later, a new population consisting of only 50\% VIA2 replaced the old one (May 10-17 1999, Figures 4, 6). 


\section{Mortality vs. behaviour}

After marking, the change in behaviour clearly violates the required assumption that all individuals have the same likelihood of capture in any given sample. Other biases such as an increase in natural mortality rate are also expected for marked glass eels (JESSOP, 2000). However, while the recaptures of JESSOP (2000) covered more than one month, most of our samples were recaptured for less than one week (Table 3). Increased natural mortality is certainly a source of overestimate in our results, but less important than the shift in migration rhythm. Mortality alone cannot explain the difference between trap and estuarine samples, which is clearly the consequence of a different behaviour. Indeed, post-marking mortalities did not exceed $7.64 \%$ in 1999 and $1.63 \%$ in 2000 in estuarine control samples. Even if they were larger than mortalities of $0.10 \%$ and $0.096 \%$ observed in the trap, they cannot explain a daily decrease of $10 \%$ of the marked glass eels observed in the estuarine samples (Table 2).

\section{Consequence of biases}

Trap-trap operations provided overestimated population estimates for the first recaptures, because dye marking induced a delayed-migration handling effect. Diminishing trends in population size were observed in successive recaptures because of the weakening of the dye effect. Increasing estimates may indicate either immigration, a switch towards benthic behaviour or an increasing mortality rate in the wild. Whatever dye was used, the lowest stock value was the best estimate.

Trap-estuary operations gave a good measure of the estuarine stock of glass eels near the dam. The supplementary assumption that active and STST glass eels had the same probability of being caught was false since both fractions displayed a different behaviour. A plausible effect of behaviour on catch probability is as follows: active behaviour led the glass eels to build up in the fishing area located immediately downstream from the dam; STST migrants oscillated in the estuary; they concentrated near the dam during spring tides and when the river flow reduced. The $20-32 \%$ variation in estimates is consistent with a smaller or larger accumulation of STST migrants near the dam, depending on tidal and flow conditions.

Estuary-estuary operations provided overestimates, sometimes very large ones. This bias increased with the number of ebb tides between marking and recapture, because of downstream emigration.

Estuary-trap estimates must comply with the additional assumption that the proportion of active glass eels within total stock is constant. This assumption was probably false at the end of the season with the loss of active behaviour. Calculations show that such a loss of the active behaviour for marked glass eels tends to underestimate the stock. Otherwise, estuary-trap estimates were less biased than estuary-estuary ones, but still were clearly overestimated when the estuarine stock consisted of a majority of STST glass eels. The decreasing stock trends for estuary-trap samples can be explained by either trap avoidance or by the transition of a fraction of the marked sample from STST to active behaviour.

To conclude, estuary-trap estimates were the only ones that tended to underestimate the stock. In contrast, all other biases such as trap shyness, mortality and departure of STST migrants tended to overestimate the stock.

\section{Fishery and ladder efficiency}

The mean efficiency of fishing trips, calculated from the maximum stock estimation was between 1 and $1.2 \%$. This confirms that fishing glass eel at an estuarine blocking dam is very efficient (BRIAND et al., 2003a). 
Relative to the active stock, the daily efficiency of the trapping ladder was $4 \%$. Considering that the active stock was $10 \%$ of the total stock, a value of $0.4 \%$ per day is very high when compared to the yearly recapture rates of (1-2\%) obtained during marking recapture operations conducted on juvenile eels (WHITE and KNIGHTS, 1997). The difference in recapture rates between the two experiments is mirrored by the decrease in migration at the yellow eel stage, yellow eel numbers representing only 1 to $6 \%$ of glass eel numbers from 1998 to 2000 (BRIAND et al., 2003a). It could be the consequence of a large mortality (BRIAND et al., 2003b) but could also illustrate the difference between the massive rheotactic migration of active glass eels and the density- dependent dispersal of yellow eels (IBBOTSON et al., 2002; FEUNTEUN et al., 2003).

Comparing trap catches with stock estimates, an efficiency of an order of magnitude of $30 \%$ is estimated for the trap 1999 and 2000. Similar calculations with JESSOP (2000) provide efficiencies of $20 \%$ at the downstream site (four Irish-style elver traps) and $40 \%$ at the upstream site (3 traps), but those were probably under-estimated as the markrecapture estimates were biased upward due to marked-fish mortality JESSOP (2000). A short duration of the active phase (one week) together with the $4 \%$ efficiency of the trapping ladder accounts for the passage of $30 \%$ of the active stock present one day in the estuary. Assuming that all glass eels pass to the active phase, a one-week duration would explain the trapping ladder efficiency. This result would also account for the reduced proportion of active migrants in the total stock, $10 \%$ of the total stock throughout the season (Figure 11). But the low efficiency of the ladder and reduced size of the active fraction could also be explained by a part of the STST glass eels switching directly to the benthic phase, and hence a longer active migration. The short duration of the active phase would be in line with the short distance covered by glass eels upstream from the tidal limit in freshwater streams (MORIARTY, 1986; NAISMITH and KNIGHTS, 1988; DUTIL et al., 1989, LOBÓN-CERVIÁ et al., 1995). However, other authors (JESSOP, 2000, DUTIL et al., 1989) describe longer migration up to 6-8+ weeks in some rivers, the distance covered reflecting the difficulty of upstream migration due to stream conditions.

\section{Delay between STST and active migration}

The transition from STST to active behaviour involves a progressive change in rheotactic behaviour (CREUTZBERG, 1961; TESCH, 2003; McCLEAVE and WIPPELHAUSER, 1987). This change in behaviour, has been associated with a delay in several species e.g. Anguilla japonica, Anguilla rostrata, Anguilla australis and Anguilla reinhardtii (TZENG, 1984; HARO and KRUEGER, 1988; PEASE et al., 2003). This delay was first linked with salinity or temperature conditions (CREUTZBERG, 1961). But other authors have argued that this delay might be needed for morphological (JELLYMAN, 1977), or physiological adaptation (DEELDER, 1958; SORENSEN and BIANCHINI, 1986; McCLEAVE and WIPPELHAUSER, 1987; PEASE et al., 2003). The glass eels collected in the downstream sector of estuaries are able to challenge the transfer to freshwater at $15^{\circ} \mathrm{C}$ (WILSON et al., 2004). The reverse is also true, as freshwater adapted glass eels are able to reactivate the mechanism of drinking and challenge full salinity (CICCOTTI et al., 1993). So the delay before entering freshwater would not be linked with their osmoregulatory capacity.

However the transition is highly dependent on temperature. The first threshold in migration concerns STST and is about $4-6^{\circ} \mathrm{C}$. Below these temperatures, glass eels remain buried in the substratum (CANTRELLE, 1981; DÉSAUNAY et al., 1987). A second temperature threshold before active migration has been described by various authors. There is probably no active migration below a threshold of $6-8^{\circ} \mathrm{C}$ in Anguilla anguilla (CREUTZBERG, 1961; TESCH, 2003). The initial ascent was observed for river temperatures of $9^{\circ} \mathrm{C}$ (GANDOLFI et al., 1984), $10-12^{\circ} \mathrm{C}$ (GASCUEL, 1986), $9-11^{\circ} \mathrm{C}$ (SCHMEIDLER, 1957) and $11^{\circ} \mathrm{C}$ (McGOVERN and McCARTHY, 1992). A threshold in 
day-degrees higher than $11^{\circ} \mathrm{C}$ was observed by (HVIDSTEN, 1983). The onset of active migration at $12^{\circ} \mathrm{C}$ was also associated with the reduction in glass eel catchability at the end of the fishing season of the river Loire in France (DÉSAUNAY et al., 1987). Threshold temperatures of $9-10^{\circ} \mathrm{C}$ were described for Anguilla austalis and Anguilla dieffenbachii by (JELLYMAN, 1977; SLOANE, 1984). In Anguilla rostrata, temperatures increasing from $12^{\circ} \mathrm{C}$ to $19^{\circ} \mathrm{C}$ triggered the onset of freshwater migration in glass eels caught with bottom traps (SORENSEN and BIANCHINI, 1986), and river temperatures were described as the most important factor determining the first migration towards fresh water (MARTIN, 1995). Stream temperatures of 10 to $12^{\circ} \mathrm{C}$ were described as a gating factor for elver runs, but to have a limited influence once this threshold was attained (JESSOP, 2003). The importance of water temperature on active migration raises the question of osmoregulatory capacity at low temperatures, which has not been studied yet (BIRRELL et al., 2000).

Recent studies suggested that a lesser activity of the thyroid gland was related to the settlement behaviour in Anguilla anguilla glass eels (JEGSTRUP and ROSENKILDE, 2003) and that an increase in T4, but not T3 plasma levels was linked to migrating behaviour in Anguilla rostrata yellow eels (CASTONGUAY et al., 1990). A different thyroidal status has been measured in the different behavioural fractions identified in the Vilaine. The glass eels ascending the ladder had a higher thyroxine (T4) level and a higher triiodothyronine (T3) level than their estuarine flood migrant counterparts (EDELINE et al., 2004). The higher whole body $\mathrm{TH}$ level was interpreted as the driver of the transition from STST to active migration, and the increased T3 level suggested an increased energy demand in the active fraction of stock. The settling glass eels, caught on the bottom at flood tide, had the lowest TH level. A further experiment in controlled conditions has shown that $\mathrm{TH}$ are involved in the regulation of locomotor activity, although the effect of thyroid hormones on rheotactism remained unclear (EDELINE et al., in press). Since increased temperatures stimulate thyroid function (LELOUP and DE LUZE, 1985) the role of temperature in migration could also be explained by a different thyroidal status, leading to a different behaviour.

The discrepancy between trap and estuarine pigmentation stages (Figures 4, 5), also observed during studies involving a migration barrier (GUÉRAULT et al., 1991; PEASE et al., 2003), can be either explained by the delay between STST and active migration, or by increased thyroid gland activity (VILTER, 1946; JEGSTRUP and ROSENKILDE, 2003; EDELINE et al., 2004). In the Vilaine estuary, we always observe a delay between the closure of the fishery and the first ascent on the ramp. This delay occurs even when water temperature are higher than $12^{\circ} \mathrm{C}$ and should allow the active migration (Figure 2). Moreover, we observed that increased water temperatures decreased the delay between the end of the fishery and the first migration (unpublished results). As the escapement from the fishery is very low (BRIAND et al., 2003a) and the presence of glass eels at the bottom of the dam is attested by the catches during the estuarine sampling trips, the delay observed probably represents the delay for transition towards active migration.

\section{CONCLUSIONS}

The mark-recapture of glass eels should be considered cautiously, unless stains with a lesser effect on behaviour are found. However, they allowed demonstration of the presence of two different behavioural fractions in the estuary, STST and active. The transition from STST to active migration was delayed, even when temperatures higher than $12^{\circ} \mathrm{C}$ should have allowed migration. As the Arzal dam is both a tidal and salinity barrier, it is unclear whether the delay is associated with a physiological adaptation to lower salinities or thyroidal activation. The active part of the stock was a fraction of the whole stock, which indicates a short duration of the active phase at this site, or the possibility that only a small fraction of the glass eel population becomes active. External factors such as density triggering active migration at the glass eel stage should be considered. Glass 
eels very rapidly switched to benthic behaviour and ceased migration. The reduced size of the yellow eel migration, when compared to the glass eel run, is explained by a very large mortality at settling, and/or an orientated massive run at the glass eel stage opposed to the diffusive migration of yellow eels.

\section{ACKNOWLEDGMENTS}

This study was supported by the Loire-Bretagne Water Agency, the European Union and national and regional funds. We thank E. LE MOAL, F. GUILLEMOT and E. LAURENT, for their contributions. We also thank J.P. BOURSE, commercial fishermen who conducted the fishing trips, B. VOEGTLE, and E. EDELINE for their collaboration. Finally, we would like to thank two anonymous reviewers and Willem DEKKER for their helpful comments.

\section{REFERENCES}

BARDONNET A., DASSE S., PARADE M. and HELAND M., 2003. Influence de l'alternance jour/nuit sur les déplacements de civelles en fluvarium. Bull. Fr. Pêche Piscic., 368, 9-20.

BIRRELL L., CRAMB G. and HAZON N., 2000. Osmoregulation during the development of glass eels and elvers. J. Fish. Biol., 56, 1450-1459.

BRIAND C., FATIN D. and LEGAULT A., 2002. Role of odour on the efficiency of an eel, Anguilla anguilla, ladder and trap. Environ. Biol. Fish., 65, 473-477.

BRIAND C., FATIN D., FEUNTEUN E. and FONTENELLE G., 2003a. Estuarine and fluvial recruitment of European glass eel in a fished Atlantic estuary. Fish. Man. Ecol., 10, 377-384.

BRIAND C., MOUNAIX B., FATIN D. and FEUNTEUN E., 2003b. Stock contribution of springtime and autumn glass eel recruitments: results based on otolith structure. Bull. Fr. Pêche Piscic., 368, 27-42.

CANTRELLE I., 1981. Étude de la migration et de la pêche des civelles (A. anguilla L. 1758) dans l'estuaire de la Gironde. Thèse $3^{\mathrm{ème}}$ cycle, Université Paris VI, Paris, 238 p.

CANTRELLE I., 1984. Le marquage par coloration appliqué à l'étude des migrations des civelles (Anguilla anguilla, Pisces, Anguillidae). Cybium, 8, 69-78.

CASTONGUAY M., DUTIL J.D., AUDET C. and MILLER R., 1990. Locomotor activity and concentration of thyroid hormones in migratory and sedentary juvenile American eels. Trans. Am. Fish. Soc., 119, 946-956.

CICCOTTI E., MACCHI E., ROSSI A., CATALDI E. and CATAUDELLA S., 1993. Glass eel (Anguilla anguilla) acclimatation to freshwater and seawater: morphological changes of the digestive track. J. Appl. Ichthyol., 9, 74-81.

CREUTZBERG F., 1958. Use of tidal streams by migrating elvers (Anguilla vulgaris, Turt.). Nature, 181, 857-858.

CREUTZBERG F., 1959. Discrimination between eeb and flood tide in migrating elvers (Anguilla vulgaris, Turt.) by means of olfactory perception. Nature, 184, 19611962.

CREUTZBERG F., 1961. On the orientation of migrating elvers (Anguilla vulgaris, Turt.) in a tidal area. Neth. J. Sea. Res., 1, 257-338.

DE CASAMAJOR M.N., 1998. Comportement migratoire de la civelle d'anguille (Anguilla anguilla L.) dans l'estuaire de l'Adour en fonction de la variabilité des conditions 
environnementales. Thèse docteur de troisième cycle, Université de Pau et des pays de l'Adour, Pau, $138 \mathrm{p}$.

DEELDER C.L., 1958. On the behaviour of elvers (Anguilla vulgaris Turt.) migrating from the sea into fresh water. J. Cons. Int. Explor. Mer, 24, 135-146.

DÉSAUNAY Y., GUÉRAULT D. and BEILLOIS P., 1987. Dynamique de la migration anadrome de la civelle (Anguilla anguilla) dans l'estuaire de la Loire: rôle des facteurs climatiques vis-à-vis de la pêche et du recrutement. IFREMER report, Nantes.

DOU S. and TSUKAMOTO K., 2003. Observations on the nocturnal activity and feeding behavior of Anguilla japonica glass eels under laboratory conditions. Environ. Biol. Fish., 67, 389-395.

DUTIL J.D., MICHAUD M. and GIROUX A., 1989. Seasonal and diel patterns of stream invasion by American eels (Anguilla rostrata) in the northern Gulf of St. Lawrence. Can. J. Zool., 67, 182-188.

EDELINE E., DUFOUR S., BRIAND C., FATIN D. and ELIE P., 2004. Thyroidal status is related to migratory behavior in glass eels of Anguilla anguilla. Mar. Ecol. Prog. Ser., 282, 261-270.

EDELINE E., BARDONNET A., BOLLIET V., DUFOUR S. and ELIE P., in press. Endocrine control of Anguilla anguilla glass eel dispersal: effect of thyroid hormones on locomotor activity and rheotactic behavior. Horm. Behav.

ELIE P., LECOMTE-FINIGER R., CANTRELLE I. and CHARLON N., 1982. Définition des limites des différents stades pigmentaires durant la phase civelle d'Anguilla anguilla L. Vie Milieu, 32, 149-157.

FEUNTEUN E., LAFFAILLE P., ROBINET T., BRIAND C., BAISEZ A., OLIVIER J.-M. and ACOU A., 2003. A Review of Upstream Migration and Movements in Inland Waters by Anguillid Eels: Toward a General Theory. In Eel Biology (eds K. AIDA, K. TSUKAMOTO and K. YAMAUCHI), pp. 181-190. Springer, Tokyo.

GANDOLFI G., PESARO M. and TONGIORGO P., 1984. Environmental factors affecting the ascent of elvers, Anguilla anguilla (L.), into the Arno River. Oebalia, 10, 17-35.

GASCUEL D., 1986. Flow carried and swimming migration of the glass eel (Anguilla anguilla) in the tidal area of a small estuary on the French Atlantic coast. Helgoländer Meeresun., 40, 321-326.

GASCUEL D., 1987a. La civelle d'anguille dans l'estuaire de la Sèvre Niortaise: biologie, écologie, exploitation, rapport global. Publications Département Halieutique, École Nationale Supérieure Agronomique, Rennes.

GASCUEL D., 1987b. La civelle d'anguille dans l'estuaire de la Sèvre Niortaise : biologie, écologie, exploitation. Méthodologie, résultats bruts. École Nationale Supérieure Agronomique, Rennes.

GASCUEL D., FEUNTEUN E. and FONTENELLE G., 1995. Seasonal dynamics of estuarine migration in glass eels (Anguilla anguilla). Aquat. Living Resour., 8, 123-133.

GUÉRAULT D., DÉSAUNAY Y., BEILLOIS P. and GRELLIER P., 1991. Étude des montées tardives de civelles et des conditions de colonisation des bassins versants de Loire et de Vilaine (février à juin, 1990). IFREMER, Rapport DRV/RH/OCEAL, Nantes.

HARO A. and KRUEGER W.H., 1988. Pigmentation, size, and migration of elvers (Anguilla rostrata, Lesueur) in a coastal Rhode island stream. Can. J. Zool., 66, 2528-2533.

HVIDSTEN N.A., 1983. Ascent of elvers (Anguilla anguilla) in the stream Imsa Norway. Rep. Inst. Freshwat. Res., 62, 71-74. 
IBBOTSON A., SMITH J., SCARLETT P. and APRAHAMIAN M.W., 2002. Colonisation of freshwater habitat by the European eel Anguilla anguilla. Freshwater Biol., 47, 1696-1706.

JEGSTRUP I.M. and ROSENKILDE P., 2003. Regulation of post-larval development in the European eel: thyroid hormone level, progress of pigmentation and changes in behaviour. J. Fish. Biol., 63, 168-175.

JELLYMAN D.J., 1977. Summer upstream migration of juvenile freshwater eels in New Zealand. N. Z. J. Mar. Freshwat. Res. 11, 61-71.

JELLYMAN D.J., 1979. Upstream migration of glass eel (Anguilla sp.) in the Waikato river. N. Z. J. Mar. Freshwat. Res., 13, 13-22.

JESSOP B.M., 2000. Estimates of population size and instream mortality rate of American eel elvers in a Nova Scotia river. Trans. Am. Fish. Soc., 129, 514:526.

JESSOP B.M., 2003. Annual variability in the effects of water temperature, discharge, and tidal stage on the migraton of American eel elvers from estuary to river. Trans. Am. Fish. Soc., 33, 3-16.

LEGAULT A., 1988. Le franchissement des barrages par l'escalade de l'anguille. Étude en Sèvre Niortaise. Bull. Fr. Pêche Piscic., 308, 1-10.

LEGAULT A., 1992. Étude de quelques facteurs de sélectivité de passes à anguilles. Bull. Fr. Pêche Piscic., 325, 83-91.

LELOUP J. and DE LUZE A., 1985. Environmental effects of temperature and salinity on thyroid function in Teleost fishes. In The endocrine system and the environment (eds B.K. FOLLET, S. ISHII and A. CHANDOLA), pp. 23-32. Japan Sci. Soc. Press, Tokyo.

LOBÓN-CERVIÁ J., UTRILLA C.G. and RINCÓN P.A., 1995. Variations in the population dynamics of the European eel Anguilla anguilla (L.) along the course of a Cantabrian river. Ecol. Freshwat Fish., 4, 17-27.

MARTIN M.H., 1995. The effects of temperature, river flow, and tidal cycles on the onset of glass eel and elver migration into fresh water in the American eel. J. Fish. Biol., 46, 891-902.

McCLEAVE J.D. and KLECKNER R.C., 1982. Selective tidal stream transport in the estuarine migration of glass eels of the American eel (Anguilla rostrata). J. Cons. Int. Explor. Mer, 40, 262-271.

McCLEAVE J.D. and WIPPELHAUSER G., 1987. Behavioral aspects of selective tidal stream transport in juvenile American eel. Trans. Am. Fish. Soc., 1, 138-150.

McGOVERN P. and McCARTHY T.K., 1992. Elver migration in the river Corrib system, western Ireland. Irish Fish. Invest., 36, 25-32.

MORIARTY C., 1986. Riverine migration of young eels Anguilla anguilla (L.). Fish. Res., 4, 43-58.

NAISMITH I.A. and KNIGHTS B., 1988. Migrations of elvers and juvenile European eels, Anguilla anguilla L., in the River Thames. J. Fish. Biol., 33, 161-175.

PEASE B.C., SILBERSCHNEIDER V. and WALFORD T., 2003. Upstream migration by glass eels of two Anguilla species in the Hacking River, New South Wales, Australia. Trans. Am. Fish. Soc., 33, 47-61.

SCHMEIDLER V.E., 1957. Entwicklung des Glassaalaufstieges in der Ems, seine zeitliche Begrenzung und die auf inn einwirkende Wassertemperatur. Z. Fish. Milfwissenschaften., 141-144. 
SEBER G.A.F., 1982. The estimation of animal abundance and related parameters. (ed C. GRIFFIN), London.

SHELDON M.R. and McCLEAVE J.D., 1985. Abundance of glass eels of the American eel, Anguilla rostrata, in mid-channel and near shore during estuarine migration. Nat. Can., 112, 425-430.

SLOANE R.D., 1984. Upstream migration by young pigmented freshwater eels (Anguilla australis australis) in Tasmania. Aust. J. Mar. Freshw. Res., 35, 61-73.

SORENSEN P.W. and BIANCHINI M.L., 1986. Environmental correlates of the freshwater migration of elvers of the American eel in a Rhode Island brook. Trans. Am. Fish. Soc., 115, 258-268.

SUGEHA H.Y., ARAI T., MILLER M.J., LIMBONG D. and TSUKAMOTO K., 2001. Inshore migration of the tropical eels Anguilla spp. recruiting to the Poigar River estuary on north Sulawesi Island. Mar. Ecol. Prog. Ser., 221, 233-243.

TESCH F.W., 1965. Verhalten der Glasaale (Anguilla anguilla) bei ihrer Wanderung in den Ästuarien deutscher Nordseeflüsse. Helgoländer Meeresun., 12, 404:419.

TESCH F.W., 2003. The eel (ed J.E. THORPE), p. 407. Blackwell Publishing, London.

TZENG W.N., 1984. Dispersal an upstream migration of marked Anguillid eel, Anguilla japonica, elvers in the estuary of the Shuang River, Taiwan. Bull. Jap. Soc. Fish. Oceanogr., 45, 10-19.

VILTER V., 1944. Conditionnement physique du «cordon " chez les civelles migratrices. C. R. Soc. Biol., 655-656.

VILTER V., 1946. Action de la Thyroxine sur la métamorphose larvaire de l'anguille. C. $R$. Soc. Biol., 783-785.

WHITE E. and KNIGHTS B., 1997. Dynamic of upstream migration of the European eel, Anguilla anguilla (L.), in the River Severn and Avon, England, with special reference to the effect of man-made barriers. Fish. Man. Ecol., 4, 311-324.

WILSON J.M., ANTUNES C. and BOUÇA P.D. and J.C., 2004. Osmoregulatory plasticity of the glass eel of Anguilla anguilla: freshwater entry and changes in branchial iontransport protein expression. Can. J. Fish. Aquat. Sci., 61, 432-442.

WIPPELHAUSER G.S. and McCLEAVE J.D., 1988. Rhythmic activity of migrating juvenile American eels Anguilla rostrata. J. mar. biol. Ass. U.K., 68, 81-91. 